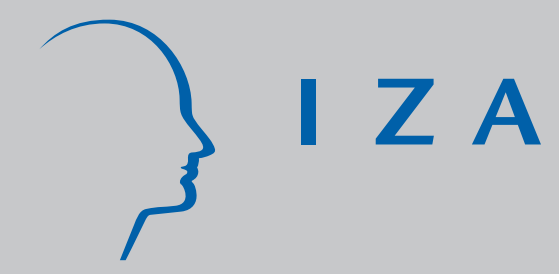

IZA DP No. 385

The Effect of Employment Protection on Worker Effort: A Comparison of Absenteeism During and After Probation

Andrea Ichino

Regina T. Riphahn

November 2001 


\title{
The Effect of Employment Protection on Worker Effort: A Comparison of Absenteeism During and After Probation
}

\author{
Andrea Ichino \\ European University Institute, Florence, CEPR, CESifo and IZA, Bonn \\ Regina T. Riphahn \\ University of Basel, CEPR, DIW and IZA, Bonn
}

Discussion Paper No. 385

November 2001

\author{
IZA \\ P.O. Box 7240 \\ D-53072 Bonn \\ Germany \\ Tel.: +49-228-3894-0 \\ Fax: +49-228-3894-210 \\ Email: iza@iza.org
}

This Discussion Paper is issued within the framework of IZA's research area Mobility and Flexibility of Labor Markets. Any opinions expressed here are those of the author(s) and not those of the institute. Research disseminated by IZA may include views on policy, but the institute itself takes no institutional policy positions.

The Institute for the Study of Labor (IZA) in Bonn is a local and virtual international research center and a place of communication between science, politics and business. IZA is an independent, nonprofit limited liability company (Gesellschaft mit beschränkter Haftung) supported by the Deutsche Post AG. The center is associated with the University of Bonn and offers a stimulating research environment through its research networks, research support, and visitors and doctoral programs. IZA engages in (i) original and internationally competitive research in all fields of labor economics, (ii) development of policy concepts, and (iii) dissemination of research results and concepts to the interested public. The current research program deals with (1) mobility and flexibility of labor markets, (2) internationalization of labor markets and European integration, (3) the welfare state and labor markets, (4) labor markets in transition, (5) the future of work, (6) project evaluation and (7) general labor economics.

IZA Discussion Papers often represent preliminary work and are circulated to encourage discussion. Citation of such a paper should account for its provisional character. 


\section{ABSTRACT}

\section{The Effect of Employment Protection on Worker Effort: A Comparison of Absenteeism During and After Probation*}

Employment protection systems are known to generate significant distortions in firms' hiring and firing decisions. We know much less about the impact of these regulations on worker effort. The goal of this paper is to fill in this gap and in particular to assess whether the provision of employment protection induces less effort among workers in the form of absenteeism.

Our analysis is based on weekly observations for the 858 white collar workers hired by a large Italian bank between January 1993 and February 1995. These workers begin to be protected against firing only after the twelfth week of tenure and we observe them for one year. We show that the number of days of absence per week more than doubles once employment protection is granted, thus confirming what is suggested by our theoretical model and what is typically assumed in the literature. We also discuss how this evidence can be used to estimate what the absenteeism rate would be in Italy if employment protection were eliminated.

JEL Classification: $\quad$ M50, J24, J31, J41

Keywords: Probation, employment protection, absenteeism, worker effort

Regina T. Riphahn

WWZ - University of Basel

Petersgraben 51

$\mathrm{CH}-4003$ Basel

Tel.: +41612673367

Email: Regina.Riphahn@unibas.ch

\footnotetext{
*We would like to thank Lazlo Goerke for his suggestions concerning the theoretical framework. We also received useful comments from Josh Angrist, Giorgio Brunello, Giulio de Caprariis, Pietro Ichino, Klaus Engelmann, Soren Johansen, Fulvio Rossi and seminar participants at Berlin, EUI, Princeton, MIT, Munich, Rutgers, UPF and Zurich. Sascha Becker provided excellent research assistance.
} 


\section{Introduction}

A large literature has studied the effect of employment protection systems on the propensity of firms to hire and fire, showing that these effects are important and capable of causing significant inefficiencies. ${ }^{1}$ Much less is known about the distortionary effects of employment protection systems on the behavior of workers. The goal of this paper is to fill in this gap and in particular to assess whether the provision of employment protection induces a reduction of worker effort in the form of increased absenteeism.

To achieve this goal we exploit "quasi-experimental" evidence from personnel data generated by the institution of probation that characterizes hiring procedures in many countries ${ }^{2}$ and in particular in Italy, the origin of our data. In the Italian case newly hired workers are subject to a probation period in which they can be fired at will by the employer. At the end of this period, full firing protection is granted to the workers. Since Italy is the OECD country with the most stringent protection against firing ${ }^{3}$, the change of job security implied by the end of probation is equivalent, from the viewpoint of the worker, to the change from a "US style" weak protection system to the most protective of the "European style" systems. Therefore, behavioral changes that occur at the end of the probation period provide a meaningful indicator of the effects of employment protection.

Note that a change from full protection to no protection was voted on in Italy in a referendum on firing regulations of May 2000. The referendum did not reach the quorum of voters and therefore the outcome did not have an effect. Had the proposal been accepted, firing regulations in Italy would have become similar to US terms overnight.

Our analysis is based on weekly observations for 858 white collar workers hired by a large Italian bank between January 1993 and February 1995. These workers were subject to a probation period of three months after which they received full protection. We observe them for one year and can therefore compare their weekly absenteeism with and without job security. We show that the number of days of absence per week more than doubles once employment protection is granted. This result can be seen as a clean test of a standard implication of rational worker behavior which has frequently been assumed in the labor economics literature. ${ }^{4}$ We also discuss, with the help of collateral evidence, to what extent this finding can be used to estimate by how much the absenteeism rate would change in Italy if employment protection

\footnotetext{
${ }^{1}$ See the initial contributions by Lazear (1990), Bentolila and Bertola (1990), Bertola (1990) and later, among others, Hopenayn and Rogerson (1993), Grubb and Wells (1994), Bertola and Ichino (1995), SaintPaul (1996), Acemoglu and Angrist (1998), Garibaldi (1998), Kugler (1999), OECD (1999) and Kugler and Saint-Paul (2000).

${ }^{2}$ See, for example, Riphahn and Thalmaier (1999) for Germany.

${ }^{3}$ See, for example, Grubb and Wells (1994) and OECD (1999). Firing costs are higher in Italy than everywhere else because this is the only country in which, if firing is not sustained by a just cause, the firm is always forced to take the employee back on payroll and to pay the full wage that the worker has lost during the litigation period plus social insurance contributions; in addition, the firm has to pay a fine to the social security system for the delayed payment of welfare contributions up to 200 percent of the original amount due.

${ }^{4} \mathrm{An}$ influential example is the efficiency wage theory proposed by Shapiro-Stiglitz (1984).
} 
were eliminated. A conservative calculation suggests that the absenteeism rate would decrease by at least 42 percent.

The paper is organized as follows. Section 2 presents a simple model of the effect of employment protection on worker effort. Section 3 describes the data and the "quasi-experiment" that generates them. Section 4 presents the basic evidence on the effect of the end of probation on absenteeism and checks its robustness. Section 5 discusses the implications for the effects of employment protection on absenteeism at the national level. Section 6 concludes.

\section{A Simple Model of the Effect of Employment Protec- tion on Worker Effort}

Consider the intertemporal decision problem of a worker who has to decide how much effort to exert on the job knowing that shirking implies a higher probability of being fired. The instantaneous utility of being employed is given by

$$
U=U(w, a)=w+a
$$

where $w$ is the wage and $a$ is absenteeism. The worker derives utility from wages and absenteeism, where the latter can be interpreted as the inverse of effort. ${ }^{5}$ Given this instantaneous utility and the discount rate $r$, the value of being employed $V^{E}$ is characterized by the following arbitrage equation:

$$
r V^{E}=w+a+(1-p) C(a)\left(V^{U}-V^{E}\right) .
$$

The left hand side is the annuity value of the utility of being employed which in equilibrium is equal to the instantaneous utility of employment plus the expected loss of utility in case of firing. The latter is equal to the product between $V^{U}-V^{E}$, which is the difference between the value of being unemployed and the value of being employed, and the instantaneous probability of firing $(1-p) C(a)$. The parameter $p \in[0,1]$ measures the degree of legal employment protection. If $p=1$ firing is not possible and therefore the probability of firing is zero. If $p=0$ no protection against firing is offered to workers. In this case the probability of firing is $C(a)$ which is assumed to be a positive and convex function of absenteeism $\left(C^{\prime}>0\right.$ and $\left.C^{\prime \prime}>0\right)$. The higher is the value of $p$ in the $[0,1]$ interval the higher is the degree of employment protection and the lower is the probability of firing for a given level of absenteeism.

If the worker is fired she becomes unemployed. The value of being unemployed is defined by the following analogous arbitrage equation:

$$
r V^{U}=b+\phi\left(V^{E}-V^{U}\right)
$$

where $b$ is income during unemployment and $\phi$ is the exogenous instantaneous probability of finding a new job in which case the worker gains $\left(V^{E}-V^{U}\right)$.

\footnotetext{
${ }^{5}$ If $e=-a$, where $e$ is effort, this utility function takes the more familiar form $U=w-e$.
} 
Solving this system of arbitrage equations for $V^{E}$, we obtain:

$$
V^{E}=\frac{(w+a)(r+\phi)+(1-p) C(a) b}{r(r+\phi)+r(1-p) C(a)}
$$

which is the objective function that the worker maximizes with respect to the level of absenteeism $a$. The first order condition, $\frac{d V^{E}}{d a}=0$, is satisfied when:

$$
X \equiv r+\phi+(1-p) C(a)-(1-p) C^{\prime}(a)(w+a-b)=0
$$

where the participation constraint $V^{E}>V^{U}$ implies that $(w+a-b)>0$.

Implicit differentiation of the first order condition gives the effect of employment protection on the optimal level of absenteeism:

$$
\frac{d a}{d p}=-\frac{X_{p}}{X_{a}}=\frac{r+\phi}{(1-p)^{2} C^{\prime \prime}(a)(w+a-b)}>0 .
$$

Thus workers are absent more often when employment protection increases. The rest of this paper is aimed at testing this hypothesis.

\section{The Data}

The firm which provides the data for our analysis is a large bank with branches all over the Italian territory and with a century-long tradition of activity at the heart of the Italian financial system. At the end of 1992, 17,971 employees worked in this bank of which 14,266 were white collar workers. From the bank's personnel office we received detailed information on the work history of 545 men and 313 females hired in white collar jobs between January 1, 1993 and February 28, 1995. ${ }^{6}$ For each hired employee we constructed a panel of weekly observations covering the first full year of tenure. During the initial three months after hiring, these workers were on probation and could be fired at will, while during the remaining nine months of the observation period they were fully protected against firing according to the standard Italian legislation. ${ }^{7}$

These 858 workers are a relatively homogeneous group of young individuals at the beginning of their career and with similar educational backgrounds. The average age is 25 and 95 percent of them are below age 30. Half of them have a college degree and all but 12 have a high school degree. The large majority of these degrees is in banking and economics (70 percent) with an additional 10 percent in law. It is also important to keep in mind that 98 percent of these

\footnotetext{
${ }^{6}$ These personnel data were also used by Ichino A. and Ichino P. (1999) and Ichino A. and Maggi (2000).

${ }^{7}$ See footnote 3 . There were also 8 other workers hired during the same period (6 men and 2 females) who separated from the firm before the end of the first year. 4 of them were fired and 4 quit to other firms for unknown motives. Since these workers could not be observed for a full year, and in particular for enough time after the end of probation, we were forced to drop them from the analysis.
} 
workers are hired at the entry level in the bank hierarchy, traditionally with internal labor market careers ahead of them.

For each worker we computed the number of days of absence officially classified as "due to illness" in each calendar week of observation. This is the indicator of absenteeism on which we will base our evaluation of the effect of employment protection on worker effort. ${ }^{8}$ Since the first calendar week of work is shorter for all workers not hired on a Monday, absenteeism in this week cannot be compared to absenteeism in later weeks. We therefore dropped the first calendar week of observation for all workers. ${ }^{9}$ Another complication is that since the length of probation is defined in months, the number of calendar weeks of probation may change across workers. All workers were however on probation for at least 12 weeks, and the corresponding observations are the ones we use to measure employees' behavior in the absence of employment protection. We consider the 40 weeks of observation after the end of probation as the period in which to evaluate absenteeism in the presence of employment protection. As a result each worker is observed for 52 calendar weeks. Our sample is therefore composed of 44,616 worker-week observations.

The majority of workers (58 percent) is absent at least once during the period of observation. However, overall, absence episodes are relatively rare: 97 percent of all worker-weekobservations are characterized by no absence. As a result, the average number of days of absence per week in the sample is low: 0.065. Note, however, that this average corresponds to an absenteeism rate of 1.3 percent of the weekly working time ( 5 days). ${ }^{10}$ Furthermore, focusing on the weeks in which absence episodes occur, their average length is 2.43 days (i.e. approximately half of the weekly working time). So, absence episodes are, in general, relatively rare events, but a majority of workers are absent at some point during the year and absenteeism implies on average a substantial loss of working time and therefore output for these workers.

\footnotetext{
${ }^{8}$ We replicated our analysis also with three other indicators of absenteeism (occurrence of an absence episode, occurrence of an episode of delay, and minutes of delay) finding qualitatively similar results, which we do not report to save space.

${ }^{9}$ Another adjustment of the duration of probation had to be made for workers who were absent during the initial probation period. Following the probation rules of the bank, we prolonged a worker's original time of probation by the number of days of absence during probation.

${ }^{10}$ For comparison, according to Confindustria - the association of Italian entrepreneurs - the average absenteeism rate in the Italian industrial sector in 1995 was 5.16 percent for blue collar workers and 2.23 percent for white collar workers (see Confindustria, Rassegna di Statistiche del lavoro, 1995). Using the Survey of Household Income and Wealth (SHIW) collected by the Bank of Italy, the average absenteeism rate for all non-self employed workers was 2.50 in the same year. We will comment again on these figures in Section 5 .
} 


\section{Absenteeism During and After Probation}

\subsection{Basic Facts}

Figure 1 depicts the extent of absenteeism during and after probation for the workers under study. Absenteeism is measured by the average number of days of absence for each of the 52 fully observed weeks of tenure. The vertical line corresponding to week 12 indicates the end of probation. This event appears to be associated with a clear change of regime. After probation the average number of days of absence is typically higher than during probation and absenteeism increases immediately after full protection is granted.

If all workers were hired in the same period of the year, for example July, probation would take place during the summer and the arrival of the fall would coincide with receiving full protection. In this case an increase of absenteeism observed after the end of probation could simply be due to seasonal effects. This is, however, not the case. Figure 1 does not change after removing the effect of calendar months, nor do the other results presented here. Thus, seasonality does not affect our results, possibly because hiring is uniformly distributed over the entire calendar year.

We want to know whether the regime change displayed in Figure 1 is the causal effect of the end of probation on the number of days of absence per week. Abstracting temporarily from the panel structure of our data to which we will return later, let $i$ denote an observation corresponding to a worker-week and $D_{i}=1$ be an indicator that probation is ended for $i$. Furthermore, using the standard notation for counterfactuals or potential outcomes, let $Y_{0 i}$ and $Y_{1 i}$ be the number of days of absence for observation $i$ in the two possible treatment situations, i.e. during and after probation, respectively. The causal effect of interest is given by

$$
\Delta \equiv E\left[Y_{1 i}-Y_{0 i}\right]
$$

and, if $D_{i}$ is independent of both $Y_{1 i}$ and $Y_{0 i}$, it follows that

$$
\Delta=E\left[Y_{i} \mid D_{i}=1\right]-E\left[Y_{i} \mid D_{i}=0\right]
$$

where $Y_{i}$ is the observed number of days of absence for unit $i$. In our case, as suggested by Angrist (1999), even if the outcome is a limited dependent variable (specifically a count variable) a simple difference between the mean days of absence during and after probation identifies the effect of the change of regime. Note also that, in the absence of possible time varying confounding factors, to which we will return in Section 4.2, our "receipt of treatment" is ignorable in the terminology of Rubin (1978) or exogenous in the more familiar econometric terminology.

In Table 1 we use regressions to estimate the conditional expectations on the right hand side of 8 , i.e. to predict the number of days of absence during and after probation. The difference between these predictions identifies the causal effect of interest. ${ }^{11}$

\footnotetext{
${ }^{11}$ Results do not change if a non-linear approximation is computed using, for example, a Poisson model.
} 
Column 1 shows that while during probation workers are on average absent for 0.034 days per week (see the intercept) at the end of probation absenteeism increases by 0.041 days. In other words, average absenteeism more than doubles when full protection against firing is granted. The other columns of Table 1 confirm that since the probation indicator is uncorrelated with a large set of controls, their inclusion in the regression does not change the effect of the end of probation. More specifically, column 2 includes 12 monthly dummies as seasonal controls. Column 3 adds gender, age, education, and marital status. In column 4 we control also for a wide set of local environmental characteristics like the location, the size, the fraction of managers and of females, the average age, and the average number of days of absence per week which characterize the worker's branch in the month before hiring. Finally, in column 5 individual fixed effects are considered, exploiting the panel structure of the data. The effect of probation is essentially unaffected and this confirms that given the exogeneity of our indicator of treatment the simple difference in means presented in the first column is sufficient to identify the causal effect of interest.

Huber-White robust standard errors are computed to control for within individual correlation of the error terms in the first four columns. They show that the effect of probation is estimated with high levels of statistical significance. The same is true for the fixed effect estimation of the last column.

On the basis of this evidence we are confident that the end of probation causes a sizeable and statistically significant increase of absenteeism. However, this does not necessarily mean that workers are more absent after the end of probation because of the higher protection against firing that they obtain. The observed association between the end of probation and absenteeism could be due to a spurious correlation between tenure and absenteeism. Alternatively it could be determined by the fact that workers simply defer absence episodes during probation to look better, in which case the effect of the change of regime would be limited to the first few weeks after the end of probation.

The next two sections consider these possible confounding factors, in order to establish whether the increase of absenteeism observed at the end of probation can be attributed specifically to the change of protection against firing.

\subsection{The Possibility of a Tenure - Absenteeism Correlation}

There are at least two plausible reasons why absenteeism may increase with tenure, independent of the existence of a probation period. One is the career concern mechanism pointed out by Holmstrom (1982): If a worker's ability is unobservable and if individual output is used by supervisors to learn about ability, workers have an incentive to exert more effort in order to bias the process of inference in their favor. However, the returns to exerting effort depend on the uncertainty about ability: Early in the process, when there is less information, supervisors put more weight on individual output when revising their beliefs. But later, when uncertainty decreases, individual output becomes less relevant for inference on ability. Hence, the incentive to exert effort is high at the beginning of a career and declines with tenure. Thus, inasmuch 
as absenteeism measures lack of effort, one would observe absenteeism growing with tenure independent of probation.

Alternatively, absenteeism might increase over the first tenure months because the worker has to learn about the social norms in the newly joined branch of the firm. If a worker derives disutility from work but needs a job to maintain her monthly income, the conflict is apparent: The individual will resolve the countervailing interests of working as little as possible and ensuring not to be laid off, by shirking as much as local employment conditions allow. If these employment conditions or social norms are unknown when the contract commences, the risk-averse worker will initially prefer to supply too much rather than too little work. Over time the individual learns about the norms and shirking increases to maximize utility subject to the perceived norm, or "no firing condition." This mechanism may also explain increasing absenteeism during early tenure months.

To establish whether these hypotheses indeed explain the significant probation effect described in Section 4.1, we repeat the analyses described in Table 1, this time adding linear tenure effects to the model. If the probation effect were simply due to the tenure profile, it should disappear once the effect of tenure is controlled for. Table 2 shows instead that the effect of the end of probation remains basically unchanged, although its statistical significance decreases slightly. ${ }^{12}$

We conclude that even in the presence of career concerns and of adaptation to social norms, the end of probation increases absenteeism in a sizeable and significant way.

\subsection{The "Deferral" Hypothesis}

Another confounding factor could be that probation reduces absenteeism by motivating individuals to postpone absences until they enjoy employment protection. Such deferral should cause an increase of absenteeism only in the first weeks after probation and not later. If this were the case, the effect of probation would be due to a change of the employment protection regime, but it would be just a temporary effect.

To test for evidence of deferral behavior, we repeated the analysis of Table 1 separating the "after probation indicator" in two dummies: one for the first month after probation and the other for later months. If the deferral hypothesis held, we would expect a higher first month effect and a lower permanent effect of protection. The results are presented in Table 3 and show no significant difference in absence behavior in the two post probation periods. Actually, absenteeism seems to be lower immediately after probation as opposed to later. Therefore, we are confident that our findings do not result from deferral behavior.

In sum, there seems to be substantial evidence suggesting that newly hired workers are significantly and permanently more absent after the end of probation. Moreover, this change

\footnotetext{
${ }^{12}$ The coefficients of the other variables included in the specifications are as in Table 1 and we omit them for brevity. If a quadratic tenure effect is considered the results remain unchanged only for males. We plan to explore in future research the reason of this peculiar gender difference.
} 
of behavior appears to be induced by the protection against firing that workers obtain when probation ends.

\section{$5 \quad$ Possibility of a Tempting Extrapolation}

The evidence presented in Section 4 shows that the number of days of absence per week more than doubles after the end of probation, thus the absenteeism rate ${ }^{13}$ when workers are not protected against firing is approximately 55 percent lower than when they obtain full protection. It is tempting to explore the possibility of using these results to evaluate how much the absenteeism rate would decrease in Italy if the degree of protection against firing were hypothetically reduced to the degree prevailing during probation in our bank (i.e. essentially no protection).

In this section we discuss whether this extrapolation is possible and meaningful. Figures 2 and 3 clarify the issue. In the above analysis we look at the difference in absenteeism around the end of probation, i.e. absenteeism level "A" after probation minus absenteeism level "B" during probation, as depicted in Figure 2. Our objective is to draw conclusions for the difference between absenteeism level "C" with employment protection minus absenteeism level "D" without employment protection, as depicted in Figure 3.

Two main issues need to be addressed: First, the newly hired workers in our bank are a homogeneous sample of young and healthy individuals at the beginning of their career, who are not representative of the population of Italian workers. This suggests that both levels "A" and "B" might underestimate the absenteeism rates that would prevail in Italy with and without employment protection. Second, reducing absenteeism for a (probation) period of just three months is likely to be easier than reducing absenteeism for the longer period which would follow a hypothetical elimination of employment protection. This suggests that absenteeism level "B" observed in our data underestimates further the absenteeism level "D" in the hypothetical situation without employment protection. If both of these concerns hold true and we underestimate "D" by more than "C", then the 55 percent reduction in the absenteeism rate during probation may overestimate the actual absenteeism response to an abolition of employment protection. In the following paragraphs we discuss evidence supporting the view that even if 55 percent is an overestimate, the likely effect of cutting back employment protection might still be substantial.

With respect to the first problem, it is indeed probable that the average absenteeism rate of our newly hired workers after probation of 1.5 percent $^{14}$ is lower than the average absenteeism rate of all Italian workers. In the industrial sector, for example, the average absenteeism rate

\footnotetext{
${ }^{13}$ The absenteeism rate is the fraction of total working time lost for absence episodes. We use this indicator to compare our results with evidence based on different datasets.

${ }^{14}$ This figure is obtained dividing the average number of days of absence per week after the end of probation $(0.075)$ by the total weekly working time of five days.
} 
in 1994 was 5.16 percent for blue collars and 2.23 percent for white collars. ${ }^{15}$ However, if the effect of probation is invariant with respect to the characteristics that reduce absenteeism in our sample below that of the population of Italian workers - an assumption which does not seem utterly implausible - an extrapolation of the probation effect measured here to the entire population is nevertheless possible.

The second issue, i.e. that it is easier to reduce absenteeism for three months than for a long and possibly indeterminate period, seems more problematic. In terms of Figures 2 and 3 , the question is whether and by how much our level "B" might underestimate the level "D" in which we are interested. In order to permit an assessment of the dimension of this possible bias we now present three pieces of evidence.

First, we obtained an indicator of the level of absenteeism in an environment without employment protection regulation, the United States. Using data from the Panel Study of Income Dynamics for the year 1992, we calculated the share of absences in total contractual working time. ${ }^{16}$ For a representative sample of fulltime employees (i.e. omitting oversample observations) this yielded an absenteeism rate of 0.87 percent, compared to our estimate of 0.68 for young Italian bank employees during their three months of probation. If we recalculate the effect of interest using this alternative estimate of the longterm level "C", the abolition of employment protection should be expected to reduce absenteeism by 42 percent. ${ }^{17}$

Second, we generated measures of worker response to financial absenteeism-related incentives. Before we can discuss this evidence (see Table 4), some institutional details must be explained. The Italian social security system (INPS) compensates industry workers for the loss of earnings if they miss work due to illness. However, INPS pays no compensation for the first three days of absence and only a partial compensation afterwards. Since the 1970s, collective bargaining has forced employers to add to the INPS payments after the third day, in order to guarantee that workers receive full pay when they are absent due to illness. For the first three days, union agreements differed across sectors. In some sectors, like metal manufacturing and chemical industries, employers had to pay fully since 1972 even for the first three days of absence. In sectors such as construction where unions were not as powerful such a favourable agreement was obtained only later or never.

Table 4 provides worker absenteeism rates for industries with and without full coverage of the first three days of absence. We can now compare differences in short term absenteeism rates with the differences in overall absenteeism rates across industries with different compensation regulations for the first three days of absence. ${ }^{18}$ In Panel A the difference in short term absen-

\footnotetext{
${ }^{15}$ See footnote 10 for source. These figures do not change much in other years.

${ }^{16}$ Individuals were asked to indicate how much work they missed due to own illness related absences. We compared that to the total contractual working time. The contractual working time was approximated as the sum of actual weeks worked, work absence weeks, vacation weeks, and weeks on strike.

${ }^{17}$ This is the percent change between 1.50 (the absenteeism rate after probation in our Italian sample) and 0.87 (the absenteeism rate without employment protection in the PSID sample).

${ }^{18}$ These rates are calculated as the ratio either between the average yearly number of hours lost for episodes of 3 days or less and the total potential yearly number of working hours, or as the ratio between the average
} 
teeism rates between construction (0.23) and metal manufacturing (0.98) in 1973 amounted to -77 percent, whereas the difference in overall absenteeism rates was much smaller at -32 percent. Clearly, there might be systematic differences in typical worker absences between these sectors. The time invariant component of these differences cancels in Panel B where we take the difference between the calculated differences. The 45 percent drop provides an indicator for the reduction of the absenteeism rate induced by eliminating the entitlement to compensation during the absence period. The figures for 1974 yield an even stronger response of 55 percent for the analogous comparison. ${ }^{19}$

These results suggest that workers do respond to the compensation systems foreseen by collective agreements for the first three days of absence. The nature of this financial disincentive to absenteeism for e.g. construction workers is comparable to the effect of loosing employment protection against firing. Inasmuch as it is plausible that the prospect of layoff is worse than that of loosing three days of pay, 45 percent could be considered a lower bound on the generalized effect of the elimination of employment protection on the absenteeism rate.

Our third piece of evidence supporting the relevance of absenteeism-related incentives uses the fact that in Italy the Chart of Workers' Rights of 1970 (Statuto dei Lavoratori) establishes that workers in enterprises with fewer than 16 employees can be fired at a very low cost ${ }^{20}$ and therefore do not enjoy the level of employment protection granted to workers in larger establishments.

Using data from the 1995 wave of the Italian Survey of Household Incomes and Wealth, we computed average absenteeism rates for a representative sample of Italian non-self employed workers, distinguished by firm size. ${ }^{21}$ Unfortunately the firm size categories in the SHIW do not match those of the employment protection regulation. However, the distinction between firms with more or less than 19 employees is sufficiently close to be informative with respect to the one which is relevant for the employment protection regulation. We find that in the group of large firms, in which workers are protected, the average absenteeism rate is 2.87 percent. In the group of small firms it is just 1.37 percent, which implies a difference of approximately 52 percent. The finding that absenteeism grows with firm size runs through the entire absenteeism literature. Many different mechanisms may actually cause this correlation including systematic differences in the age and health of employees in different types of firms. ${ }^{22}$ When we control for gender, age, education, sector, qualification, geographical area, and self-declared health status, the percentage difference between the average absenteeism rates in the two groups of firms remains basically unchanged. If employment protection is the causal mechanism of this residual effect, the difference between the absenteeism rate of large and smaller firms can be

yearly number of hours lost for all episodes and the total potential yearly number of working hours.

${ }^{19}$ The two figures, -45 and -55 percent, encompass the range of similar estimates that we have obtained for other pairs of sectors characterized by similar differences in regulations and which we omit for brevity.

${ }^{20}$ Basically "at will", as in the US, until 1990, and later at a cost not higher than six months of wages in case of unjustified firing. See footnote 3 for the regulations concerning workers in larger firms.

${ }^{21}$ Absenteeism rates are here calculated as the fraction of days of absence in a standard 240 workday year.

${ }^{22}$ See e.g. Barmby and Stephan (2000) and the literature cited there. 
considered as an approximate measure of the effect of interest.

In sum, the absenteeism response to the removal of employment protection based on employer size amounts to 52 percent. 45 percent is instead the measure based on the different financial incentives for short absences by sector, while 42 percent is the measure obtained with PSID data. All three indicators are smaller than the 55 percent described in Section 4 based on the effect of probation. However, all suggest strong employee responses to absenteeism-related incentives. While 55 percent may overestimate the magnitude of the response when extrapolating to the overall labor force, it is based on the cleaner "experiment" and does present a statistically and economically highly significant effect. Despite the undisputeable pitfalls of each of these alternative measures, they suggest consistently that the effect of removing employment protection on absenteeism rates is likely to be relevant and probably not smaller than 42 percent.

\section{Conclusions}

Using the "quasi-experimental" evidence generated by the institution of probation periods, we have shown that the end of these periods is associated with a significant increase of absenteeism. This result provides support to the hypothesis of rational worker behavior which we specify in our theoretical model and which is typically assumed in the labor economics literature.

Our sample considers 858 newly hired Italian white collar workers during their first 52 weeks of tenure, of which the initial 12 are weeks of probation. The end of probation implies an increase of job security comparable to a change from a "US style" weak protection system to the most protective of the "European style" systems. We argue that the behavioral change observed at the end of probation is a causal effect of the change of employment protection.

We discuss the conditions under which this causal interpretation is plausible and extrapolate an estimate of the decrease in the absenteeism rate that would be induced in Italy by the elimination of employment protection. Our evidence suggests that the decrease of absenteeism would range between 42 and 55 percent.

It is important to point out that absenteeism is but one dimension of employee behavior where incentives deriving from employment protection may be effective. Numerous additional dimensions, such as delays at work, misdemeanors, playing computer games or surfing the internet, and overall worker effort were not considered here. It seems plausible that behavioral adjustment to the presence of employment protection encompasses all of these dimension. Thus a correct and reliable estimate of the precise cost of employment protection regulation is difficult to derive.

We have no criterion to establish whether the effect on worker effort that we estimate is large or small, nor do we want to venture into an evaluation of whether it is socially optimal to offer employment protection when this causes a loss of output. However, since empirical estimates of this incentive effect did not exist in the literature, our finding may be informative. 


\section{References}

Angrist J. (1999), "Estimation of Limited-Dependent Variable Models with Binary Endogenous Regressors: Simple Strategies for Empirical Practice", Journal of Business and Economic Statistics 19(1), 2-16.

Acemoglu D. and J. Angrist (1999), "Consequences of Employment Protection? The Case of The Americans with Disabilities Act", NBER WP 6670.

Barmby T. and G. Stephan (2000), "Worker Absenteeism: Why Firm Size May Matter", Manchester School 68(5), 568-577.

Bentolila S. and G. Bertola (1990), "Firing Costs and Labor Demand: How Bad is Eurosclerosis?", Review of Economic Studies 57(3), 381-402.

Bertola G. (1990), “Job Security, Employment and Wages”, European Economic Review 34(4), 851-866.

Bertola G. and A. Ichino (1995), "Wage Inequality and Unemployment: US vs. Europe", Bernanke, B. and J. Rothemberg (eds.), "NBER Macroeconomics Annual 1995", MIT Press, 13-66.

Garibaldi P. (1998), "Job Flow Dynamics and Firing Restrictions", European Economic Review $42(2), 245-75$.

Grubbs D. and W. Wells (1994), "Employment Regulations and Patterns of Work in EC Countries", in OECD "Economic Studies" 21, 7-58.

Holmstrom B. (1982), "Managerial Incentive Problems - A Dynamic Perspective" in: Essays in Economics and Management in Honor of Lars Wahlbeck. Helsiniki: Swedish School of Economics, reprinted in: Review of Economic Studies 66(1), 169-182.

Hopenhayn H. and R. Rogerson (1993), "Job Turnover and Policy Evaluation: A General Equilibrium Analysis", Journal of Political Economy 101(5), 915-938.

Kugler A. D. (1999), "The Impact of Firing Costs on Turnover and Unemployment: Evidence from the Colombian Labour Market Reform", International Tax and Public Finance 6(3), 389-410.

Kugler A. D. and G. Saint-Paul (2000), "Hiring and Firing Costs, Adverse Selection and Long Term Unemployment", Universitat Pompeu Fabra, mimeo.

Ichino A. and G. Maggi (2000), "Work Environment and Individual Background: Explaining Regional Shirking Differentials in a Large Italian Firm" Quarterly Journal of Economics 115(3), 1057-1090. 
Ichino A. and P. Ichino (1999), "Discrimination or Individual Effort? Regional Productivity Differentials in a Large Italian Firm" in: John C. Haltiwanger et al. (eds.), The Creation and Analysis of Linked Employer-Employee Data, North-Holland, 59-77.

Lazear E. P. (1990), "Job Security Provisions and Unemployment", Quarterly Journal of Economics 105(3), 699-726.

OECD (1999), "Employment Outlook", chapter 2, Paris.

Riphahn R. and A. Thalmaier (2001), "Behavioral Effects of Probation Periods: An Analysis of Worker Absenteeism", Journal of Economics and Statistics 221(2), 179-201.

Rubin, D. (1978), "Bayesian Inference for Causal Effects: the Role of Randomization", The Annals of Statistics 6, 34-58.

Shapiro, C. and J. Stiglitz (1984), "Equilibrium Unemployment as a Worker Discipline Device", American Economic Review 74(3), 433-444.

Saint-Paul E. P. (1996), "On the Political Economy of Labor Market Flexibility", in Bernanke, B. and J. Rothemberg (eds.), "NBER Macroeconomics Annual 1996", MIT Press, 151-196. 
Table 1: Weekly days of absence during and after probation

\begin{tabular}{|c|c|c|c|c|c|}
\hline & 1 & 2 & 3 & 4 & $\overline{5}$ \\
\hline Effect of the end of probation & $\begin{array}{l}0.041^{*} \\
(0.008)\end{array}$ & $\begin{array}{l}0.040^{*} \\
(0.008)\end{array}$ & $\begin{array}{l}0.040^{*} \\
(0.008)\end{array}$ & $\begin{array}{l}0.040^{*} \\
(0.008)\end{array}$ & $\begin{array}{l}0.041^{*} \\
(0.005)\end{array}$ \\
\hline Female & & & $\begin{array}{l}0.035^{*} \\
(0.012)\end{array}$ & $\begin{array}{l}0.036^{*} \\
(0.012)\end{array}$ & \\
\hline Age & & & $\begin{array}{c}0.001 \\
(0.002)\end{array}$ & $\begin{array}{c}0.001 \\
(0.002)\end{array}$ & \\
\hline Years of schooling & & & $\begin{array}{c}-0.005^{*} \\
(0.002)\end{array}$ & $\begin{array}{c}-0.005^{*} \\
(0.002)\end{array}$ & \\
\hline Married & & & $\begin{array}{c}0.014 \\
(0.018)\end{array}$ & $\begin{array}{c}0.011 \\
(0.018)\end{array}$ & \\
\hline Branch located in the south & & & & $\begin{array}{l}-0.024 \\
(0.010)\end{array}$ & $\begin{array}{c}0.017 \\
(0.060)\end{array}$ \\
\hline Size of the branch & & & & $\begin{array}{c}0.000 \\
(0.000)\end{array}$ & $\begin{array}{c}0.001 \\
(0.001)\end{array}$ \\
\hline Fraction of managers in the branch & & & & $\begin{array}{c}0.035 \\
(0.033)\end{array}$ & $\begin{array}{c}0.023 \\
(0.047)\end{array}$ \\
\hline Fraction of females in the branch & & & & $\begin{array}{c}0.024 \\
(0.049)\end{array}$ & $\begin{array}{l}-0.008 \\
(0.074)\end{array}$ \\
\hline Average age in the branch & & & & $\begin{array}{c}0.001 \\
(0.001)\end{array}$ & $\begin{array}{c}0.001 \\
(0.003)\end{array}$ \\
\hline Days of absence per week in the branch & & & & $\begin{array}{l}-0.005 \\
(0.005)\end{array}$ & $\begin{array}{l}-0.005 \\
(0.011)\end{array}$ \\
\hline Intercept & $\begin{array}{c}0.034^{*} \\
(0.006)\end{array}$ & $\begin{array}{l}0.055^{*} \\
(0.013)\end{array}$ & $\begin{array}{c}0.076 \\
(0.051)\end{array}$ & $\begin{array}{c}0.055 \\
(0.080)\end{array}$ & \\
\hline Seasonal controls & no & yes & yes & yes & yes \\
\hline Individual fixed effects & no & no & no & no & yes \\
\hline
\end{tabular}

Note: The table reports linear regression results for the dependent variable: number of days of absence per week. All time varying branch characteristics are measured in the month before the worker is hired. Standard errors are reported in parentheses (Huber-White robust in the first four columns). 
Table 2: Weekly days of absence during and after probation, controlling for tenure

\begin{tabular}{lccccc}
\hline \hline & 1 & 2 & 3 & 4 & 5 \\
\hline Effect of the end of probation & $0.035^{*}$ & $0.042^{*}$ & $0.042^{*}$ & $0.042^{*}$ & $0.043^{*}$ \\
& $(0.012)$ & $(0.011)$ & $(0.011)$ & $(0.011)$ & $(0.008)$ \\
Time trend & yes & yes & yes & yes & yes \\
Seasonal controls & no & yes & yes & yes & yes \\
Individual controls & no & no & yes & yes & yes \\
Local controls & no & no & no & yes & yes \\
Individual fixed effects & no & no & no & no & yes \\
\hline \hline
\end{tabular}

Note: The table reports linear regression results for the dependent variable: number of days of absence per week. Individual controls are gender, age, years of schooling, and marital status. Local controls are the location, the size, the fraction of managers and of females, the average age and the average number of days of absence per week, which characterize the branch of the worker in the month before hiring. Standard errors are reported in parentheses (Huber-White robust in the first four columns).

Table 3: Evidence on the deferral hypothesis

\begin{tabular}{lccccc}
\hline \hline & 1 & 2 & 3 & 4 & 5 \\
\hline First month after probation & $0.032^{*}$ & $0.035^{*}$ & $0.035^{*}$ & $0.035^{*}$ & $0.036^{*}$ \\
& $(0.011)$ & $(0.010)$ & $(0.010)$ & $(0.010)$ & $(0.009)$ \\
Other months after probation & $0.042^{*}$ & $0.041^{*}$ & $0.041^{*}$ & $0.041^{*}$ & $0.042^{*}$ \\
& $(0.008)$ & $(0.009)$ & $(0.009)$ & $(0.008)$ & $(0.005)$ \\
Seasonal controls & no & yes & yes & yes & yes \\
Individual controls & no & no & yes & yes & yes \\
Local controls & no & no & no & yes & yes \\
Individual fixed effects & no & no & no & no & yes \\
\hline \hline
\end{tabular}

Note: The table reports linear regression results for the dependent variable: number of days of absence per week. Individual controls are gender, age, years of schooling, and marital status. Local controls are the location, the size, the fraction of managers and of females, the average age and the average number of days of absence per week, which characterize the branch of the worker in the month before hiring. Standard errors are reported in parentheses (Huber-White robust in the first four columns). 
Table 4: Absenteeism rates with different regimes of compensation during absence periods

\begin{tabular}{|c|c|c|}
\hline Sec & $\overline{\overline{1973}}$ & 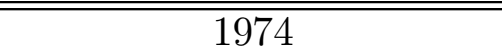 \\
\hline agr & 3 days or less & 3 days or less all episodes \\
\hline
\end{tabular}

Panel A

Metalmanufacturing

Full compensation for

0.98

8.98

1.74

9.57

all days of absence

Construction

No compensation for the

0.23

6.11

0.34

7.11

first 3 days of absence

\section{Panel B}

Difference in difference

for metal manufacturing

and constructions

Note: Panel A reports absenteeism rates measured as the ratio of average yearly hours lost for (short or all) illness episodes and total potential working hours. For each year, the first column refers only to absence episodes that lasted 3 days or less. The second column refers instead to all absence episodes. Panel B reports the following difference in difference calculations:

$$
\frac{\left(r_{s c}-r_{s m}\right)}{r_{s m}}-\frac{\left(r_{a c}-r_{a m}\right)}{r_{a m}}
$$

where $r$ denotes an absenteeism rate, $m$ denotes metal manufacturing, $c$ denotes constructions, $s$ denotes short episodes and $a$ denotes all episodes.

All figures are the result of our calculations based on statistics published by Confindustria (the confederation of Italian private employers) in Rassegna di statistiche del lavoro (various years). 


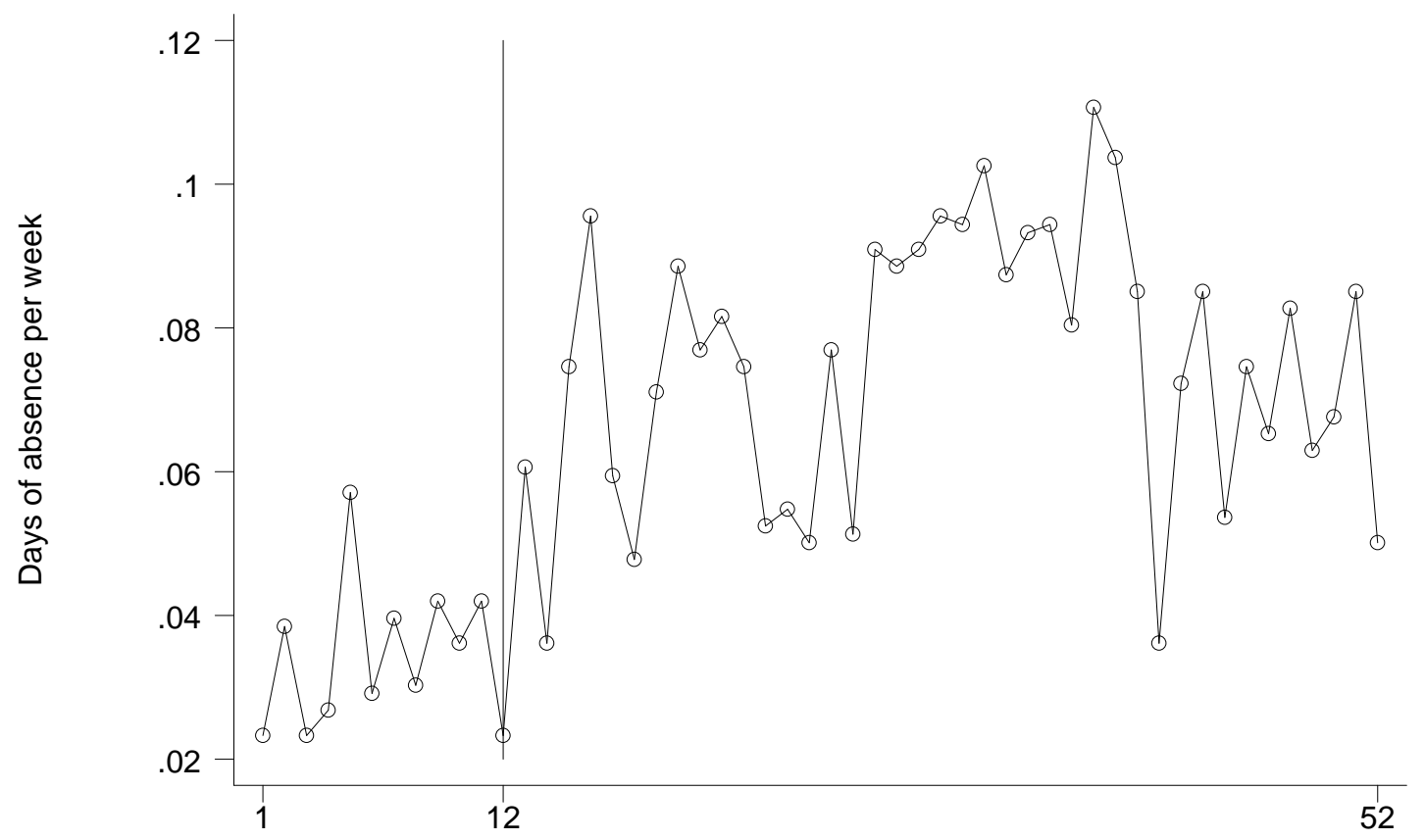

Fig. 1: Absenteeism during and after probation - All workers 


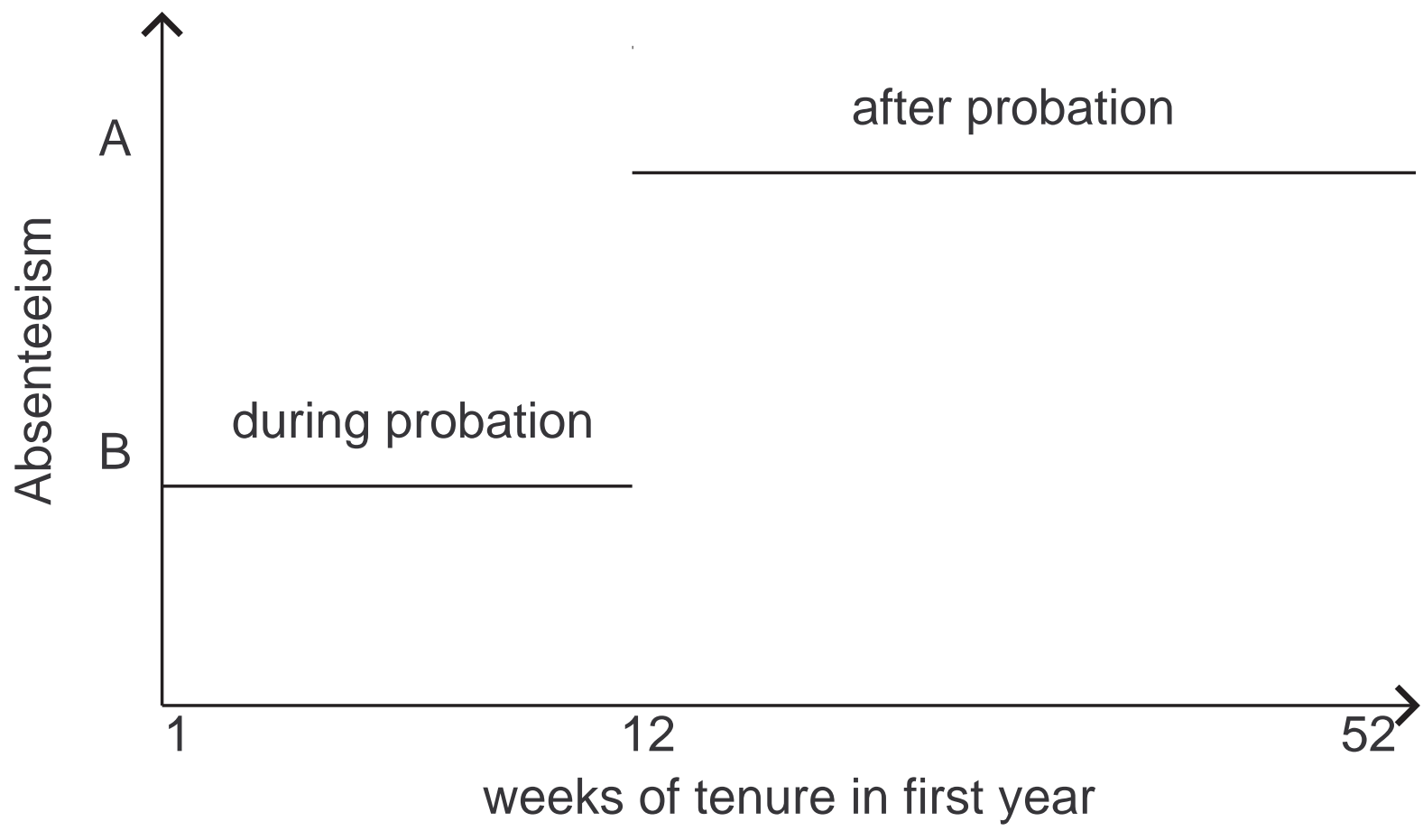

Fig. 2: Observed effect of the end of probation

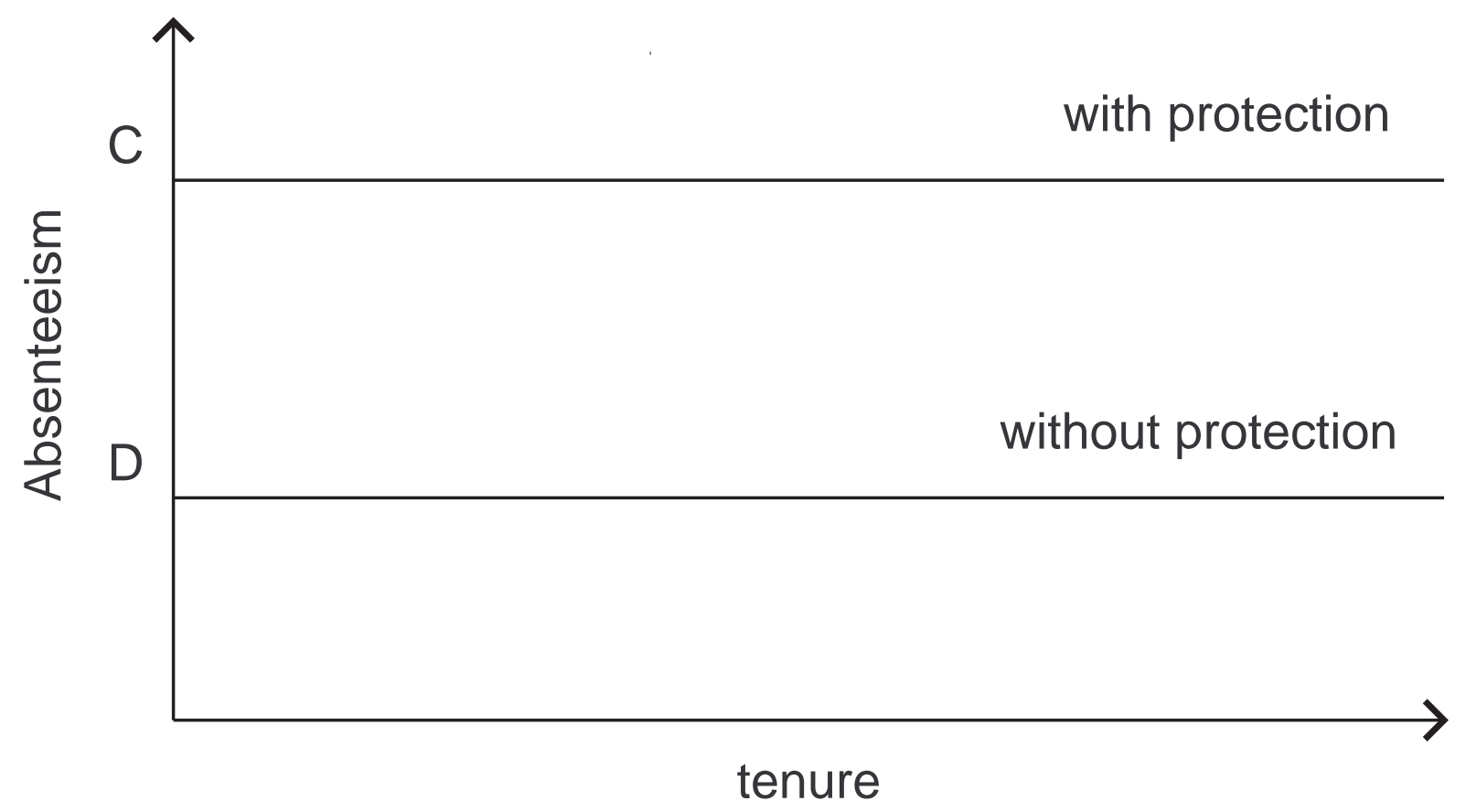

Fig. 3: Unobservable effect of a change of protection 


\section{IZA Discussion Papers}

\begin{tabular}{|c|c|c|c|c|}
\hline No. & Author(s) & Title & Area & Date \\
\hline 371 & $\begin{array}{l}\text { S. C. Wolter } \\
\text { A. Zbinden }\end{array}$ & $\begin{array}{l}\text { Rates of Return to Education: The View of } \\
\text { Students in Switzerland }\end{array}$ & 5 & 09/01 \\
\hline 372 & $\begin{array}{l}\text { J. Konings } \\
\text { H. Lehmann }\end{array}$ & $\begin{array}{l}\text { Marshall and Labour Demand in Russia: Going } \\
\text { Back to Basics }\end{array}$ & 4 & 09/01 \\
\hline 373 & S. J. Trejo & $\begin{array}{l}\text { Does the Statutory Overtime Premium } \\
\text { Discourage Long Workweeks? }\end{array}$ & 1 & $10 / 01$ \\
\hline 374 & $\begin{array}{l}\text { G. J. van den Berg } \\
\text { B. van der Klaauw }\end{array}$ & $\begin{array}{l}\text { Counseling and Monitoring of Unemployed } \\
\text { Workers: Theory and Evidence from a } \\
\text { Controlled Social Experiment }\end{array}$ & 6 & $10 / 01$ \\
\hline 375 & $\begin{array}{l}\text { J. A. Dunlevy } \\
\text { W. K. Hutchinson }\end{array}$ & $\begin{array}{l}\text { The Pro-Trade Effect of Immigration on } \\
\text { American Exports During the Late Nineteenth } \\
\text { and Early Twentieth Centuries }\end{array}$ & 1 & $10 / 01$ \\
\hline 376 & G. Corneo & Work and Television & 5 & $10 / 01$ \\
\hline 377 & S. J. Trejo & $\begin{array}{l}\text { Intergenerational Progress of Mexican-Origin } \\
\text { Workers in the U.S. Labor Market }\end{array}$ & 1 & $10 / 01$ \\
\hline 378 & $\begin{array}{l}\text { D. Clark } \\
\text { R. Fahr }\end{array}$ & $\begin{array}{l}\text { The Promise of Workplace Training for Non- } \\
\text { College-Bound Youth: Theory and Evidence } \\
\text { from German Apprenticeship }\end{array}$ & 1 & $10 / 01$ \\
\hline 379 & $\begin{array}{l}\text { H. Antecol } \\
\text { D. A. Cobb-Clark }\end{array}$ & $\begin{array}{l}\text { The Sexual Harassment of Female Active-Duty } \\
\text { Personnel: Effects on Job Satisfaction and } \\
\text { Intentions to Remain in the Military }\end{array}$ & 5 & $10 / 01$ \\
\hline 380 & M. Sattinger & $\begin{array}{l}\text { A Kaldor Matching Model of Real Wage } \\
\text { Declines }\end{array}$ & 7 & $10 / 01$ \\
\hline 381 & $\begin{array}{l}\text { J. T. Addison } \\
\text { P. Teixeira }\end{array}$ & The Economics of Employment Protection & 3 & $10 / 01$ \\
\hline 382 & L. Goerke & Tax Evasion in a Unionised Economy & 3 & $11 / 01$ \\
\hline 383 & $\begin{array}{l}\text { D. Blau } \\
\text { E. Tekin }\end{array}$ & $\begin{array}{l}\text { The Determinants and Consequences of Child } \\
\text { Care Subsidies for Single Mothers }\end{array}$ & 3 & $11 / 01$ \\
\hline 384 & $\begin{array}{l}\text { D. Acemoglu } \\
\text { J.-S. Pischke }\end{array}$ & Minimum Wages and On-the-Job Training & 1 & $11 / 01$ \\
\hline 385 & $\begin{array}{l}\text { A. Ichino } \\
\text { R. T. Riphahn }\end{array}$ & $\begin{array}{l}\text { The Effect of Employment Protection on Worker } \\
\text { Effort: A Comparison of Absenteeism During } \\
\text { and After Probation }\end{array}$ & 1 & $11 / 01$ \\
\hline
\end{tabular}

